\title{
World Cinema Will not Work
}

\author{
William Brown \\ University of Roehampton, UK \\ William.Brown@roehampton.ac.uk
}

\begin{abstract}
In this essay, I engage with the concept of 'world cinema,' identifying ways in which the term 'world' might always already come loaded with masculine and, in particular, white connotations, such that a turn to 'world cinema' runs the risk of reaffirming the centrality of masculinity and whiteness - at a time when, perhaps it is of utmost importance, for the sake of the continuation of human and other life, to challenge and perhaps even to negate that centrality. What applies to 'world' (which may be a shorthand for white masculinity) may also apply to cinema, and so it is that cinema and white masculinity alike that must be abandoned for human life on Earth to progress. To propose a turn to world cinema may thus not 'work' as a means to develop film studies in an ethical, more inclusive direction, since both world and cinema are by nature exclusive, rather than inclusive.
\end{abstract}

\section{Keywords}

world cinema - non-cinema - colonialism - whiteness - black cinema

The Old English term woruld means 'human existence' and/or 'the affairs of life,' with the human thus being a central component of the derived concept 'world.' This is borne out in the Proto-Germanic *weraldi-, or 'the age of man,' which stems from *wer, meaning 'man' (from which we also get werewolf, or 'man-wolf,' with *wer itself stemming from the Latin vir, meaning 'man' or 'hero') and *ald, meaning 'age,' from the Proto-Indo-European root *al-, meaning 'to grow' or 'to nourish.' Within religious thought, the world thus connotes human life on earth - as opposed to the afterlife. 
In an era when we are supposed to be thinking 'after finitude' (see Meillassoux, 2009), such that we paradoxically consider a world without men (which is, from the etymological perspective, a world that is not a world), the concept of 'world cinema' becomes problematic. For, if 'the posthuman turn' tells us anything, then it is that the 'world' is not a 'world' of and for men, and that 'heroism' has historically led to the creation of a planet in which the conditions of life for multiple species, perhaps including our own, become untenable. That is, the contemporary era perhaps is looking beyond (human) life ('after life'), such that to consider 'world cinema' - a cinema of the age of men, especially men as heroes - is always already antiquated.

Maybe some rehabilitation of 'world' can be had in thinking about werecinema, as if the human were, like the werewolf, symbiogenetically evolving with cinema and other technologies, with the result that what we have is no longer human exactly, but a hybrid human-machine, or a werecinema. Such a chimerical perspective would in principle decentralise the human, but it would still perhaps overly emphasise the masculine (vir), as well as perhaps cinema. And it would assume that somehow man was at one point something other than his technology, even if tools perhaps define man more than vice versa, as the opening of 2001: A Space Odyssey (Stanley Kubrick, UK/USA, 1968) would want to suggest. Humans, or perhaps specifically men, always were werecinema (if 'cinema' here can represent technology), which in turn means that they were never really men if men can be isolated from the rest of the planet. The creation of a world, then, so important apparently to human storytelling, including human cinematic storytelling, is precisely the creation of man as distinct from the rest of the planet. It is to separate man from the planet, which primordial separation allows that man to treat that planet not as a living multiplicity with which he has a symbiotic (read: dependent) relationship, but as a dead entity that he can use and abuse as he sees fit (the world is not perceived to 'nourish' man, but rather man perceives himself as constituting the world). It is, in other words, for the world to become dead to man, such that man can then 'kill' and consume that world over and over again, since it is just a carcass that we ravage rather than being a living entity that sustains us. To 'turn' to 'world cinema,' then, is perhaps to reinforce two technologies - man and cinema - of planet killing.

But hold on, we might say. To turn to world cinema is an attempt precisely to think beyond the hegemonic and to begin to include within our thinking the 'minor,' as well as that which does not fit within the old paradigms, from the national to the industrial to the transnational, even as 'world cinema' would hope, for scholars like Lúcia Nagib (2006), to be able to include those old paradigms as well. This is not just a facile claim that 'world cinema' must de facto 
be 'world cinemas', as if substantives, when used in abstract fashion (to talk of 'cinema' conceptually) did not always imply plurality (there can be no man without men, no cinema without cinemas). Rather, it is to try to create a level playing field in which hegemony, or imbalances of power, are undermined as we (attempt to) give equal credence and respect to all cinemas... perhaps even including those cinemas that are not cinemas, especially if not every society can (or would want to) produce the same cinema, or even produce cinema at all, and yet which societies 'we' would want equally to recognise as real, as politically and aesthetically important, not least in the sense of being part of the 'world picture.'

'Sure' is the response to such a contention - and this effort to include is in many ways laudable, even as it risks being at worst colonial (it means everyone has to be or to become cinematic, which may also mean becoming patriarchal if cinema-as-tool is part and parcel of the invention of man-as-separate-fromthe-world), and at best condescending (I place 'we' in 'scare' quotes above because who is/are 'we' to be determining the stakes of reality, at the very least on a politico-aesthetic level, in the first place? and who is/are 'we' to 'bring in' others who by definition were previously excluded, as if that exclusion could simply be forgotten thanks to the dictates of fashion, which is to say the dictates of capital, which is perhaps the excluding mechanism, or the mindset of separation, that created this whole problem in the first place - if the concept of 'picturing' the world is also not always already an exclusive mechanism?).

If 'we' is anyone, then, it is man as he has defined himself in contradistinction not only to a planet that he abuses as if it were not alive/as if it were dead, but also in contradistinction to other humans who historically have been abused as if not alive, as if not human. Such abjected and excluded humans-that-arenot-human have included and continue to include women, people of colour, those who might broadly define themselves as queer, those perceived as disabled, and, of course, the poor. 'World cinema' might aim to include both the included and the excluded, i.e. to include. But whose inclusion is this? Indeed, if David Martin-Jones (2019) has recently contended that the 'turn' to transnational cinema is 'really' a turn to 'world cinema,' then this begs the question of who is doing the turning, and why they were facing the other/'wrong' way for so long up until this point in time. That is, can one not query the exclusive nature of the simultaneously temporal and spatial perspective that is offered when we speak 'only now' of a 'turn' to 'world cinema'?

The colonial project involves the imposition on other people of rules that the colon(ial)ist does not themselves respect or keep. That is, while, say, England imposes upon its people the ideological apparatus of the nation in order to control them (people living within a particular space begin to think 
of themselves as 'English'), so does it impose upon all of the territories and peoples that it colonises the concept of the nation, such that they adopt various national identities, too. And yet, as is clear from a nation ruled by a queen of German origin married to a Greek man and whose family was, at a certain point in time, involved in 'running an Empire' (i.e. profiting from vast 'extra' territories beyond their 'national' 'home'), the ruling classes care not so much for the nation; they use it as a mechanism for discipline and control, creating borders to regulate all manner of different territories. It is, if you will, the difference between the tourism of the rich (crossing borders with ease) and the migration of the dispossessed and the persecuted (illegal border crossings, human trafficking). One can only 'carve up' a dead body, and so the carving up of space in order to divide it among the rich demonstrates that to the rich, the world is dead. In other words, the rich have always had a/the whole world as their playground, and to be 'global' or 'cosmopolitan' thus runs the risk of being an expression of planet-killing richness rather than being an expression of pan- or trans-territorial solidarity. Those who 'turn' must, as mentioned, have been facing the other way up until now. They must have turned their backs on that 'world,' such that they can now turn to it. To 'turn' to world cinema is thus an admission of solipsism (my perspective is the only perspective), while perspective itself, like any picture, involves a frame, and thus excludes, and perhaps even kills or treats as dead meat (since it carves up space as if it were dead meat).

In this sense, to 'turn' is an expression of specifically vertebrate thought; it is an expression of creatures who have backs. 'I've got your back,' we might be saying to global conspecifics when we 'turn' to world cinema. And yet, many people in the world have had their backs broken as a result of the back-breaking labour that they have been and are forced to undergo during the processes of extraction that have made, and which continue to make, the rich world rich. There is no 'back' for us to have, then, with the possessive dimension (I have got your back) connoting a sense of the theft that took and takes place when that back was/is broken and when those materials were/are thieved (I've got your back, because you don't have a back anymore as a result of my having made you sacrifice it for me by sending you underground to extract minerals). In this sense, there is also no turning back, no going back, no opportunity to make anything 'great' 'again, because all going back will only ever be a repetition ('back once again' with a renegade [i.e. uncaring] master [generally male]). It will be a revolution rather than an evolution. World cinema will thus put cinema to work, further breaking its back, such that in the end it will not work, because, its back broken, its veins bled dry, carved up like meat, it can work no longer. It will have been mined. It will have possessively become mine. 
When Gilles Deleuze (2005) says that cinema can at the best of times reconnect us with the world, he is perhaps suggesting that cinema can take us back to the world, i.e. to the age of man. Cinema in this sense becomes a pharmakon, presenting itself as cure for a primordial separation of man from world that in fact it reinforces. 'Cinema' is in this sense as problematic as 'world' as something to which we might 'turn' in the contemporary era. Maybe it is both man and cinema that must equally be abandoned if we are to evolve... Or if world cinema will not work, perhaps it can nonetheless play.

The Greek term heros connotes not just a hero but also a 'demigod,' and thus a hero is somehow beyond the human. If the virile world is a heroic world (a world of narrative?), it is a world in which man is a demigod while all others are cast into the realm of the subhuman (kings and queens never respected national boundaries, even as they got their subjects to fight over them in a bid to get them to believe in those boundaries, i.e. to become subjugated; nations were never about space, but the subjugation of people). If world (from vir) and cinema (creating worlds, creating the world as picture, including the pictures that are maps and flags, the borders and meanings of which become more real to us than the seamless biosphere that nourishes us)... if these are both mechanisms for subjugation, then perhaps both must be resisted even as we hope the 'turn' to 'world cinema' to be an act of auto and allo-emancipation from subjugation (it frees us and 'others' from domination).

And yet, let us recall that for Deleuze there is no world but rather a monde, which potentially springs from the Etruscan $M r \oplus$, or $m u \vartheta$, meaning 'pit.' That is, to reconnect not with the world but with the monde is to reconnect with the muddy filth that is the source, the spring, the mine of all life (the germinating earth nourishes us all). It is not to abject others, but to abject oneself. It is to be covered in dirt. To reconnect with the monde is to be black while to reconnect with the world is to want to make the world white again - as man becomes a byword for white man. Proper man. Clean man. A man of and believing in property (owning but not going down the mine). Capitalist man.

But even as we might all try to be black now, in a period when Achille Mbembe suggests a 'Becoming-Black-of-the-World' (2017:7), can we really do this? Can we forget the history of the world, which is to say the history of white, capitalist men, defined as it is by racial and other forms of violence? As Celine Parreñas Shimizu finds whiteness unwatchable (see Miller, Rodríguez and Parreñas Shimizu, 2018), and as she elsewhere 'gnaws at the whiteness' of cinema studies (Parreñas Shimizu, 2017), she perhaps also implies that cinema studies, as a white study of a white screen, cannot 'turn' to 'world cinema' precisely because it is to impose the narrative of white cinema studies and of heroic white men (those who make the 'world' as such, those who make the 
world as 'picture,' the world as man), to continue with white men as narrators, to continue with narrative and picture-making as fundamentally white. ${ }^{1}$ Maybe cinema is white. Maybe black cinema is impossible. Indeed, can one even picture blackness without negating pictures as such?

But if we cannot abandon history (which is not to say that to forget is impossible; to forget is, on the contrary, very possible, and perhaps even 'necessary' for the white world if it is to continue, since otherwise it risks creating a situation of such gravity that it falls into a black hole, i.e. it falls into its grave, back in the mud - underground with the already-black and buried, the already-treated-as-if-dead bodies that otherwise sustain it in its whiteness and property on the planet's surface, up in the cosmetic cosmos and away from the chthonic chaos below)... but if we cannot abandon history, then what can we do? We can perhaps play and have fun, engaging in (anglophone?) language games, turning to world cinema(s). But perhaps this also is only to perpetuate a world of privilege, to perpetuate world-as-(exclusive-white-)privilege.

Can we get, at the last, beyond language? Can we get 'just' to cinema, cinema as a medium beyond language, cinema as just, a black (non-)cinema? Maybe we must abandon study (logos as word, as language). No more cinema. No more film studies. No more world. This is the future, the muddy black pit (monde), the grave, that awaits the white world, while also being the black underside, the very history of that same world (black history, becoming history, is the future of whiteness, the death of the sun, the Becoming-Black-of-the-World, history becoming future as future becomes history: evolution). With this pit we must connect, not colonisingly to render it $\log o s$ (i.e. not to destroy its very pit-ness, reigniting a dying star with white cinema and cinematic weapons of whiteness, i.e. nuclear bombs), but as part of the white world's own necessary and ecstatic destruction. Maybe until then 'we' should just do what we want and turn to world cinema, because maybe it makes no difference. But maybe 'we' (white men and their victims) should start to consider what awaits (the death of everything) before it is too late and we (white men? all?) realise that we never, none of us ever, even began to think during our brief time with this planet.

1 At the end of 'Gnawing at the Whiteness of Cinema Studies,' Parreñas Shimizu presents Ang pagdadalaga ni Maximo Oliveros/The Blossoming of Maximo Oliveros (Auraeus Solito, Philippines, 2005) and Serbis (Brillante Mendoza, Philippines/France/South Korea/Hong Kong, 2008) as two examples of how 'Asian American cinema decenters whiteness' (Parreñas Shimizu, 2017: 124). Given that neither film is Asian American, this becomes a curious claim. Perhaps non-American (non-western) cinema will decenter whiteness more powerfully. Perhaps non-cinema will also help to do this. 


\section{References}

Deleuze, G. (2005). Cinema 2: The Time Image (trans. Hugh Tomlinson and Robert Galeta). London: Continuum.

Martin-Jones, D. (2019). Transnational turn or turn to world cinema? Transnational Screens, 10:1, pp. 13-22.

Mbembe, A. (2017). Critique of Black Reason (trans. Laurent Dubois). Durham, N.C.: Duke University Press.

Meillassoux, Q. (2009). After Finitude: An Essay on the Necessity of Contingency (trans. Ray Brassier). London: Continuum.

Miller, J. R., Rodríguez, R. T. and Parreñas Shimizu, C. (2018). The Unwatchability of Whiteness: A New Imperative of Representation. Asian Diasporic Visual Cultures and the Americas, 4, pp. 235-243.

Nagib, L. (2006). Towards a Positive Definition of World Cinema. In: Dennison, S. and Lim, S. H. eds., Remapping World Cinema: Identity, Culture and Politics in Film. London: Wallflower, pp. 30-37.

Parreñas Shimizu, C. (2017). Gnawing at the Whiteness of Cinema Studies: On Asian American Media Now. Cinema Journal, 56:3 (Spring), pp. 119-124. 